\title{
Effective Employee Engagement in the Workplace
}

\author{
Schrita Osborne \\ Walden University \\ Mohamad S. Hammoud \\ Walden University
}

\begin{abstract}
Disengaged employees typically cost U.S. corporations $\$ 350$ billion annually. The purpose of this case study was to explore strategies that some communication business leaders use to engage their employees. The target population consisted of four communication business leaders in Jackson, Mississippi, who possessed at least 1 year of successful employee engagement experience. The self-determination theory served as the study's conceptual framework. Semistructured interviews were conducted, and the participating company's archived documents were gathered. Patterns were identified through a rigorous process of data familiarization, data coding, and theme development and revision. Interpretations from the data were subjected to member-checking to ensure trustworthiness of the findings. Based on the methodological triangulation of the data collected, prominent themes emerged from thematically analyzing the data: rewards and recognition, empowering employees, and building a bond between leaders and employees.
\end{abstract}

Keywords: human resources, disengagement, productivity, leadership

\section{Introduction}

The survival of corporate industries is dependent on maximizing profits from existing capabilities, while recognizing and adjusting to the fact that what may work today may not necessarily work in the future (Kortmann, Gelhard, Zimmermann, \& Piller, 2014). To make or maintain their companies' profitability, leaders of companies must work hard to engage employees (Kortmann et al., 2014). However, leaders may sometimes struggle to adapt their organization in response to change if they limit their focus to existing products and processes (Hill \& Birkinshaw, 2012). Understanding how to manage the balance between employee relations, adopting innovation, and maximizing short-term profits is critical to business leaders ensuring a viable future for their corporations (Hill \& Birkinshaw, 2012).

The use of advanced technologies, skilled labor, best practices, and education has helped to increase the efficiencies in many major organizations and firms. However, disengaged employees who have lowered productivity since the 2008 financial meltdown have affected the financial performances of many U.S. organizations (Purcell, 2014). The longevity of an organization is affected by employee engagement, which is a factor on the financial performance of the organization (Bersin, 2014). In contrast, improved employee productivity had a positive effect on organizational financial performance.

Organizational productivity is determined by employees' efforts and engagement (Musgrove, Ellinger, \& Ellinger, 2014). Interpersonal behaviors affect productivity; consequently, organizational 
leaders have begun to monitor how different interpersonal behaviors influence productivity (Hausknecht \& Holwerda, 2013). Negative effects on productivity could be caused by negative interpersonal behaviors that lower employee engagement. Bersin (2014) found that only $13 \%$ of worldwide employees are fully engaged at work. In addition, twice as many are so disengaged that this negative behavior is spread to other employees (Bersin, 2014). Leaders of U.S. corporations who incorporate strategic employee engagement behaviors may experience higher employee productivity. This study is limited by the knowledge, experience, skills, and techniques of communication business leaders in Jackson, Mississippi, and the strategies they use to engage their employees.

\section{Research Purpose and Research Question}

The purpose of this qualitative case study was to explore strategies that some communication business leaders use to engage their employees to increase profits. Interviews were conducted to seek the insights of communication business leaders, within Jackson, who had been successful with employee engagement for at least a year. These leaders shared their successful employee engagement strategies through open-ended questioning sessions. The Jackson communication business leaders who learned and deployed effective employee engagement strategies noted better organizational cohesion. The following research question was used to guide this research:

Research Question: What strategies do communication leaders use to engage their employees to increase profits?

\section{Research Design and Sampling}

The case study research design was appropriate for the study because the intent was to explore the processes, practices, and programs of experienced communication business leaders; sharing this rich data may contribute to a better understanding of employee engagement. Case study research involves the understanding of complex issues and emphasizes the understanding of the context in a limited set of conditions and relationships between conditions (Basurto \& Speer, 2012; Bruin, McCambridge, \& Prins, 2014; Marshall \& Rossman, 2014). Researchers have used case studies to explore and conduct comprehensive analyses of experiences, which promotes better understanding of real-world contexts (Bezrukova, Thatcher, Jehn, \& Spell, 2012). The case study involves more than conducting research on a phenomenon (Anderson, Leahy, DelValle, Sherman, \& Tansey, 2014; Cairney \& St. Denny, 2014; Yin, 2013).

For this research, the case study was within a single organization based in Jackson. The organization selected for this case study was founded in 1875 and has grown to a multibillion-dollar industry in over 200 countries, suggesting the members of the organization selected have achieved success with engaged employees and for organizational profitability. Sampling in a qualitative study includes using a small number of participants or locations to collect information to generalize the findings to a limited geographic location (Silverman, 2015).

The sample selected for this single case study was four communication business leaders who have had at least 1 year of proven success with employee engagement in an organization with more than 200 employees. Purposeful criterion sampling was used to select the participants (Anderson et al., 2014; Li \& Titsworth, 2015; Marshall \& Rossman, 2014). For this research, four participants were appropriate to reach saturation. Data saturation was accelerated by conducting member-checking and reviewing of archival data. 


\section{Review of the Literature}

The review of the literature of this study begins with self-determination theory (SDT) as the foundation for understanding the importance of implementing new strategies to an organization. The next section of the literature review addresses employee engagement as a learning process to explore the unique challenges of implementing processes to support productivity and profitability. The remainder of the literature review includes four sections on employee engagement, impact of employee engagement, organizational culture, and leadership.

\section{Self-Determination Theory}

The theory of work engagement, SDT, was formally introduced in the mid-1980s by Deci and Ryan (1985) to examine employee motivational factors. Deci and Ryan developed the SDT, which has been used in professional and academic research that relate to employee engagement. SDT relates to natural or intrinsic tendencies to behave in healthy and effective ways. Employee engagement and human behaviors have a connection to the SDT and the essence of work engagement (Deci \& Ryan, 1985). An employee's level of engagement derives from his or her being able to control personal behaviors and goals.

Disengagement and personal engagement are related to the SDT in that an employee's behavioral state is a key driver of motivation to demonstrating behavior at the professional and personal levels. The engagement level of employees affects the productivity of an organization. The motivation level of an employee is related to job satisfaction. The emotional state of an employee also relates to motivation (Deci \& Ryan, 1985). When employees begin to withdraw, and hide their identities, ideas, and feelings, they become disengaged and defensive, resulting in an adverse effect on work performance (Deci \& Ryan, 1985).

Employee engagement strategies implemented by business leaders result in higher levels of employee engagement (Blattner \& Walter, 2015), customer satisfaction, productivity, and profit (Bowen, 2016), and lower levels of employee accidents and turnovers (Barrick, Thurgood, Smith, \& Courtright, 2014). Business leaders adopt the concept of SDT to enable employees to hold positive attitudes toward their organization (Mowbray, Wilkinson, \& Tse, 2014).

\section{Employee Engagement}

Employee engagement is critical to any organization. Deci and Ryan conducted the most influential study on employee engagement in 1985 (Berens, 2013). Deci and Ryan (1985) expanded on early work by differentiating between intrinsic and extrinsic motivation. Competence, autonomy, and psychological relatedness which are psychological needs, motivate the individual to initiate behavior essential for psychological health and well-being of an individual and if satisfied may lead to optimal function and growth (Deci \& Ryan, 1985). The basic needs of satisfaction have been found to directly relate to dedication of employees (Vandenabeele, 2014).

Dedicated and meaningful work enables employees to realize how valuable they are within the organization and makes them engaged. Bolman and Deal (2014) suggested there is an opportunity for employees' autonomy when SDT is leveraged, and furthermore, employees can influence those around them. This influence transcends to the benefits of intrinsic rewards. Meaningful work will allow for an increase in employees' participation; however, it does not guarantee that the employee will be engaged. The need for autonomy, intrinsic rewards, and influence are required to achieve employee engagement (Bolman \& Deal, 2014).

Employee motivation is attributed to the concepts of the SDT. La Guardia (2009) suggested that psychological needs form a sense of development of identity by intrinsic motivation, which results in 
the outcomes of interest and engagement. Using potentials and commitment can influence an individual's value, behavior, and goals, which are healthy factors for an individual's identity (La Guardia, 2009). Fullagar and Mills (2008) found a significant relationship between intrinsic motivation and flow experiences. Flow is the holistic sensation that employees feel when they are totally engaged within their work (Fullagar \& Mills, 2008). The relationship between intrinsic motivation and flow supports considering engagement as the psychological need of autonomy.

Assessing demographic characteristics as they relate to employee engagement provides knowledge of demographic trends within the labor force (Buttner, Lowe, \& Billings-Harris, 2012). Business leaders can engage younger workers by monetary compensation. Younger workers leave their organizations for lack of monetary compensation even when the occupation is consistent with their needs and desires (Butler, Brennan-Ing, Wardamasky, \& Ashley, 2014). Millennials are not willing to make personal sacrifices for a career and are less loyal to their organizations (Festing \& Schafer, 2014). Baby Boomers are less prone for monetary reward and more to processes and loyalty to their organization (Saber, 2013). Business leaders can engage Baby Boomers by ensuring a long-term contract and a process-oriented organization (Saber, 2013). Millennials are more likely to turnover when they feel there is no opportunity for promotion or increases in pay within the organization (Hayes, 2015). Therefore, when considering dismissal or disengagement strategies, human resource practitioners may better serve their organizations by dismissing a Millennial rather than a Baby Boomer (Hayes, 2015).

\section{Impact of Employee Engagement}

The failing global economy has created a huge shift in the way business takes place (McCuiston \& DeLucenay, 2010). Employee engagement matters to both the employee as well as the organization. Employees can utilize contract agreement provisions to impede the attainment of the organizational goals and objectives. Management's capability to leverage employee engagement strategies is essential in an organization.

Cooper-Thomas, Paterson, Stadler, and Saks (2014) establishing that high levels of expectations and frequent performance reviews can increase employee participation and cooperation. The scarcity of resources has lead organizations to think more about reducing costs and increasing productivity and efficiency. Reduced variation in processes can reduce cost over time as it relates to process improvement (Emrouznejad, Anouze, \& Thanassoulis, 2010); however, an organization must continue to incorporate processes that enhance employee engagement. McCuiston and DeLucenay (2010) noted short-term cost cutting processes are not uniformly successful.

Employee engagement has emerged as one of the greatest challenges in today's workplace. With complexities and stringent regulations in many organizations, employee engagement will continue to challenge organizations in the future (Mishra, Boynton, \& Mishra, 2014). This aspect challenges management because engagement is a critical element in maintaining the organization's vitality, survival, and profitability (Albercht, Bakker, Gruman, Macey, \& Saks, 2015; Breevaart et al., 2013; Farndale \& Murrer, 2015). Organizations that have highly engaged employees have greater profits than those that do not (Society for Human Resource Management [SHRM], 2014). Organizations with highly engaged employees experience increased customer satisfaction, profits, and employee productivity (Ahmetoglu, Harding, Akhtar, \& Chamorro-Premuzic, 2015; Carter, 2015; CooperThomas et al., 2014; Vandenabeele, 2014).

\section{Leadership}

Leaders that are authentic influence the engagement of employees (Nicholas \& Erakovich, 2013). Balancing moral perspectives with interpersonal relationships can create a healthy leadership- 
employee relationship. Employee engagement, a byproduct of leadership, is improved when the leader has a direct relationship with employees (Lowe, 2012). Ensuring work engagement and empowerment plays a significant role in employee involvement (Nicholas \& Erakovich, 2013). Effective leadership provides vision and direction for employee development (Souba, 2011). The ability for leadership to effectively communicate is a basis for employee engagement.

The main focus of employee engagement is the alignment of the employee with the organizational goals and to go beyond what is expected (Menguc, Auh, Fisher, \& Haddad, 2013). Anitha (2014) suggested employee engagement reflects two essential elements: (a) willingness to contribute to organizational success and (b) a positive and energized employee who is at a motivational state (Eldor \& Harpaz, 2015). Karanges, Johnston, Beatson, and Lings (2015) defined engagement as the extent in which employees are willing to commit both emotionally and rationally within their organization, how long they are willing to stay as a result of that commitment, and how dedicated they are to their work.

Employee engagement is related to the psychological experiences of people who shape their work process and behavior. Employee engagement is multidimensional; engaged employees are emotionally, physically, and cognitively engaged in their daily work (Eldor \& Harpaz, 2015). The organization has the responsibility to provide for the needs of employees by providing proper training and building a meaningful workplace environment; in turn, employees have the responsibility to provide a meaningful contribution to the organization. Many organizations perceive the importance of employee engagement; however, the issue of how to increase the level of employee engagement is not warranted (Wang \& Chia-Chun, 2013).

\section{Organizational Culture}

Organizations must provide a psychologically safe workplace to improve employee engagement (Kompaso \& Sridevi, 2010). The culture of psychological ownership and engagement begins when leaders create a psychologically safe workplace (Dollard \& Bakker, 2010). The manner in which an individual feels satisfied and enthusiastic in work-related activities fosters employee engagement (Nasomboon, 2014). Organizations should develop training programs that focus on skills to influence employee performance and engagement. Kompaso and Sridevi (2010) described engaged employees as those who have an emotional connection with the organization. Service training increases engagement and has a direct effect on the organization's profits (Granatino, Verkamp, \& Parker, 2013).

The U.S. Department of Labor (2015) identified employee engagement as a challenge, with a negative percentage of $35 \%$ or higher for organizations. Therefore, organizational leaders are rapidly finding ways to engage employees for long-term employment. Engaged employees are noted to having lower turnover rates and higher retention (Ahmetoglu et al., 2015). Thirty percent of U.S. employees are engaged at work, and a staggeringly low 13\% worldwide were engage (Beck \& Harter, 2015). In addition, within the past 12 years, these percentages have changed minimally, meaning that worldwide, a high number of employees fail to develop and contribute at work.

Researchers have studied employee engagement and have applied it among various organizations. Employee engagement is often referred to as organizational commitment or organizational citizenship (Slack, Orife, \& Anderson, 2010) and is an emotional and intellectual commitment to an organization (Andrew \& Sofian, 2012; Meyer, Stanley, \& Parfyonova, 2012). Farndale and Murrer (2015) defined employee engagement as when employees harness themselves physically, cognitively, and emotionally while completing daily tasks. Saks and Gruman (2014) synthesized employee engagement within two categories: attention and absorption. The amount of time an employee 
spends thinking about his or her role in an organization is referred to as attention. The level of intensity an employee engages within their current roles is referred to as absorption.

\section{Data Processing and Analysis}

Interviews with the participants occurred in a setting where participants felt comfortable to provide detailed responses. The follow-up, probing questions varied according to the interview question and experience of the participant. The objective of each probing question was for the participant to expound on his or her experience. To maintain confidentiality, each participant was assigned a code of I1, I2, I3, or I4.

In addition to face-to-face interviews, employee personnel files and company policies regarding employee engagement strategies were reviewed to triangulate and confirm interview data. Document review included the company engagement policies. Communication business leaders utilize the company engagement policies as guidelines for improved employee engagement, to encourage consistent company policy, and to ensure legal compliance. Participants I1 and I4 confirmed the findings identified in their company's employee engagement policy. For example, the company's employee engagement policy indicated that leaders should (a) focus on discussing and addressing the root causes of issues, (b) strive for steady progressive improvement, and (c) avoid focusing on an arbitrary, absolute engagement score.

A six-steps data analysis approach was used: (1) read through all the data, (2) organize and prepare the data for analysis, (3) begin detailed analysis with a coding process, (4) advance how the description and themes will be represented in the qualitative narrative, (5) use the coding process to generate a description of the setting or people as well as categories or themes for analysis, and (6) develop an interpretation or meaning of the data (Johnson, 2015; Lalor et al., 2013; Yin, 2013). NVivo 11 software was used for data coding and exploration of themes. The NVivo 11 is appropriate for creating categories (Gilbert, Jackson, \& DiGregorio, 2013).

\section{Results}

\section{Rewards and Recognition}

Based on the coded responses of the communication business leaders and archival records, rewards, and recognition reflected Deci and Ryan's (1985) SDT framework. For example, I1 indicated leaders must implement incentives to engage employees. According to Brick (2012), recognition is critical to the culture and operation within the workplace, which impacts workforce engagement. Also, employee rewards and recognition directly affect employee performance and are a form of powerful feedback. The strategies I1 identified were in alignment with Haines and St-Onge's (2012) findings that rewards and recognition directly affect employee engagement and performance. I3 indicated that employees wish to feel appreciated and valued when performing daily tasks. The need for autonomy, intrinsic rewards, and influence are required to achieve employee engagement (Bolman \& Deal, 2014). Competency and recognition are fostered when leaders provide employees with the opportunity to communicate issues they may experience, or provide input about operations within the workplace (Yuan, Lin, Shieh, \& Li, 2012).

All participants indicated that for most employees, pay is the positive outcome of working. However, feelings of stability and insurance are more important than pay (I2, I1). When employees are competent and recognized, group dynamics converge to create a sense of ownership of outcomes, workplace environment, and organization (Avey, Wernsing, \& Palanski, 2012). According to I1, with rewards and recognition systems in place, the atmosphere becomes more harmonious, thus creating a sense of work enjoyment amongst employees. 
Data from company employee engagement policies confirmed that employees are regularly asked to participate in activities designed to foster an enhanced work environment. Organizational leaders also provide participation incentives. When addressing the company policy, I2 agreed regular activities have increased employee engagement; as a result, employees exceeded their quota goals, which increased company profits. I2 indicated that local communication business leaders make efforts to promote creative, energetic, and passionate employees who also demonstrate dedication to a high standard of excellence. To boost employee engagement, all participants mentioned yearly events, such as time off, center dinners, off-site events, and bonuses. Promoting cultural competence of the entire organization means enhancing employee competency. McDaniel, Ngaia, and Leonard (2015) noted the most significant topics for performance development and evaluation include competency enhancement. Annual appraisals assess an employee's level of competency; as such, these evaluations directly contribute to high morale and increased engagement. Compensation was perceived to being more valuable than employee relations (Mullen, Fish, \& Hutinger, 2010). I1 asserted that the employee who strives for additional responsibilities is sought out because he or she will be more likely to be rewarded with greater compensation and the opportunity for advancement within the organization.

I2 and I3 encouraged employee engagement by providing nonfinancial rewards or even changing employees' daily routine. Employee engagement is related to the psychological experiences of people who shape their work process and behavior. Improved employee engagement is a multidimensional process, best achieved through enhanced employee emotional, physical, and cognitive daily work engagement (Eldor \& Harpaz, 2015). For example, I2 and I3 met employee's physiological needs by providing snacks throughout the day, extending breaks, offering reward books, and conducting morning cheers. Other rewards and recognition practices identified by I4 were gift cards, an employee-of-the-month parking space, and raffle drives.

The company's employee engagement policy mentioned providing a safe work environment for all employees. The organizational leaders have the responsibility to provide for the needs of employees by providing proper training and building a meaningful workplace environment. In turn, employees have the responsibility to provide a meaningful contribution to the organization. All participants' responses aligned with studies conducted by Gallup Consulting and SHRM, which indicated that organizations that have highly engaged employees have greater profits than those that do not (Mann \& Darby, 2014; SHRM, 2014).

\section{Empowering Employees}

The research findings provided clues in identifying the needs and challenges leaders face while empowering employees. All participants indicated that employees desire a challenge in their work and want leaders to trust them in completing their assigned tasks. Further, all participants believed employees should receive the necessary training and resources to do their jobs. Deci and Ryan (1985) referred to competence as the effectiveness and the use of an individual's skills, which allows him or her to work at high levels. Employees that are confident in themselves are confident in their daily work duties. Hynes (2012) suggested leaders employ processes that address employee needs and expectations' concerns, such as corporate culture awareness, team skills development, incentives, and communication. I3 and I4 recommended increasing opportunities for employee empowerment and development. I4 stated employees' opportunity for job advancement and development play a critical role in improving engagement. All participants mentioned that career growth and empowerment were key determinants of job performance and engagement. Changes in empowerment, training, and developmental programs can affect employee engagement.

I4 agreed with the company's policy on employee engagement, in that the company provides a variety of development programs to accelerate the employee's career path and gain new leadership 
skills. I4 further stated that employees that feel empowered to do their jobs and know that there are opportunities for advancement demonstrate increased employee engagement. Career growth and development is one of the predictors of employee engagement. I1 pointed out a strategy used to boost employee engagement by providing quarterly training to ensure employees have all the knowledge needed for high performance. Ledlow and Coppola (2013) claimed mentorship involves openness, equality, and trust between the mentor and the mentee. Vallerand (2012) believed that employee motivation has a direct impact on employee commitment and performance. In accordance with the company's employee engagement policy, leaders recommend employees for enhanced developmental programs. All participants suggested that recommending employees for enhanced developmental programs has improved employee engagement, in that employees feel leaders care about their success and organizational engagement.

All participants indicated the need for employees to have personal goals. These personal goals influence how well an employee performs at work. Employee commitment and performance determine organizational success (Shahid \& Azhar, 2013). I1 and I2 believed leaders who fail to help employees meet personal goals can negatively influence engagement.

All participants have implemented strategies designed for an employee with the potential to become part of the leadership team and advance within the organization. The company's employee engagement policy included a hands-on curriculum for shaping employees into leaders. I2 indicated that listening is an essential element in helping employees reach their personal goals and to feel empowered. I2 stated that when employees vent, they offer leaders clues about their success needs. I2 stated that these clues are critical to employee empowerment; leaders must find a way to cultivate the employee's needs. All participants' responses aligned with Talib's (2013) conclusions in that an employee's overall performance is an essential component in an organization's success. All participants claimed that once an employee has a sense of empowerment, his or her engagement and performance then exceed expectations. I2 indicated many employees yearn for advancement opportunities. I4 indicated the need to conduct weekly team meetings to address employee's concerns. Of these weekly meetings, I4 stated they provide an opportunity for the leader to encourage employees by delineating the necessary steps for advancement. I2 and I3 stated that many employees want to move up in the organization. However, many employees are not aware of the available opportunities. As a remedy, I1 conducts quarterly meetings with employees to encourage advancement, promote empowerment, and improve employee engagement. Korzynski (2013) believed that employees that have proper growth and development channels could better select a career development track to meet their growth needs. All participants indicated the importance of providing adequate development and growth opportunities.

When leaders apply Deci and Ryan's (1985) SDT, their leadership strategies will transform the work environment to ensure employees can reach their full potential. I1 indicated that empowerment enables an employee to have a sense of value within the organization. Ugwu, Onyishi, and Rodriguez-Sanchez (2014) suggested empowerment involves identifying the rights of employees and providing them with the proper resources for being successful. Organizational leaders that actively foster opportunities and engage the learning and developmental process create more profit, more satisfied employees, and enjoy higher retention rates (Carter, 2015; Schramm, Coombs, \& Boyd, 2013). For example, Latif (2012) measured employee retention at $59 \%$ for an organization with employee-focused learning development. All participants indicated that an employees' sense of being valued helped the employee feel connected to, and identify as, a part of the organization. According to Belle, Burley, and Long (2014), employees desire to be accepted, respected, and included in the organizational decision-making process. I2 indicated that employees who have a desire for empowerment are those that were more cognizant of the procedures. Organizations that have a healthy and conducive workplace environment are much more sustainable than their competition (Schramm et al., 2013). I4 suggested that organizational leaders must cultivate employees 
holistically to ensure employee engagement for a more harmonious workplace environment. Finally, all participants' responses aligned with the SDT by referring to competence as the effective use of an individual's skills, which allows him or her to work better.

\section{Building a Bond Between Leaders and Employees}

Leaders have an influential role in improving employee engagement. Leaders have been proven to influence and motivate employees through demonstrating clear values and fostering positive teamwork in an agreeable manner as indicated by Kouzes and Posner (2012) and Yukl (2012). Both I1 and I4 indicated that employees who exhibit enthusiasm in completing their work duties, also show a strong bond between that employee and their leader. Review of the company's policy on employee engagement confirmed I1 and I 2 responses that a strong relationship between an employee and leader fosters a healthy team environment and can increase job satisfaction and productivity. When employees are engaged, their individual performance is high, which can positively impact overall organizational performance. Flexible and adaptive leaders are critical in today's organizations (Crossman \& Crossman, 2011). A successful business often boasts a driving force of excellent leadership.

All participants indicated the essentials of having effective communication between employees and leaders. Communication plays a significant role in employee engagement (Welch, 2012). I2 and I3 indicated that leaders should be as good at listening as they are at being authoritative. I4 claimed effective communication is imperative to meet company goals. I1 indicated effective communication increases the positive bond between employee and leader. I2 indicated being creative in the workplace environment increases employee engagement. I3 gives team members opportunities to critique leaders in various areas. I3 further stated that obtaining feedback from employees gives leaders insights regarding strategies to implement for improved employee engagement that results in increased profits. All participants indicated employees' responses on communication between employee and leaders is essential to the employees' success in the organization. Leaders of organizations that fully support employees, promote continuous learning, and are transparent in their decision-making, have a greater impact on the increased level of employee engagement (Morgeson, Aquinis, Waldman, \& Siegel, 2013). I3 indicated when providing feedback to employees, leaders must be positive, as this improves the relationship between leaders and employees. In an environment where the employee feels valuable and worthwhile, there is a meaningful bond between the leaders and employees (Song, Kolb, Lee, \& Kim, 2012). I1 indicated that many employees come from various backgrounds; to strengthen the bond and relationship, leaders need to know how to communicate with each employee.

All participants expressed the importance of building trust with employees to improve engagement. I2 indicated that employees are more willing to do all they can for leadership when they are confident leadership will have their backs. I2 further stated that with the number of diverse employees, an effective leader could identify, develop, and help employees advance. I2 responses clearly aligned with the SDT, for example, the basic need of satisfaction relates to employee dedication (Vandenabeele, 2014). I1 stated if our organization's customer base is diverse and we can meet their needs, leaders should be adequately prepared to manage a diverse employee base.

A positive organizational culture can promote competitive work environments and continuous improvements (Morgeson et al., 2013). Therefore, leaders that foster a generative organizational culture encourage development and growth for themselves and their employees. Fehr and Gelfand (2012) implied an organization's culture included its leader's core values, beliefs, and observed norms. I4 suggested an effective organization does use diversity just to have legitimacy with the customer base but uses their diverse employee environment to increase cultural awareness and appreciation. I2 suggested that understanding various cultures is not easy; leaders must create an 
environment where all employees feel appreciated and engaged. I1 further indicated leaders must cultivate a workplace culture in which every employee is valued for their unique contributions, as this bond invokes employees to achieve their highest potential.

Leaders influence depends on the leadership ability to connect emotionally with employees. I1 suggests this kind of leader can influence employee engagement. Researchers, who have conducted prior research, clearly outline that leadership, retention, and culture are intertwined. Leaders influence culture by acceptance of core organizational values and providing a positive environment with clear communication and engaging employees (Men \& Stacks, 2013).

The convergence of leadership methods could assist organizational leaders in better managing employee actions, needed for a more collaborative approach to completing workplace tasks. All participants suggested various leadership strategies to improve employee engagement and confirmed the transformational leader is the most identified with and the most effective at the organization. Choudhary, Akhtar, and Zaheer (2012) described the transformational leader as one that motivates employees, generate awareness, and builds a relationship with them. I2 suggested being able to identify the need for change while creating a vision and being inspiring is critical to fostering the employee and leadership relationship. I1 identified that an effective leader could understand the future and see and articulate that vision. Such a leader will ignite employee enthusiasm and create a stronger employee-leader bond. To promote employee engagement, organizational leaders must understand the use of intellectual capital and the needed behaviors to drive perfect task completion.

I4 indicated the importance of creating trust between an employee and leader. I4 further indicates collaboration increases trust between an employee and leader. Both I1 and I2 believe leaders must increase the employees' satisfaction and engagement. Under such a leader, employees are more likely to transcend their self-interest for the sake of the organization. I1 believes an effective leader should be fair and have a sense of integrity. Transformational leaders enhance the interests by increasing the level of needs of employees that relate to self-fulfillment, self-actualization, and achievement (Li, Gupta, Loon, \& Casimir, 2016). I3 believes an effective leader is willing to implement new and innovative ways for employees to remain engaged. I3 found that building an employee's self-esteem further strengthen the employee and leader bond and relationship. I3's response aligned with Schaubroeck, Lam, and Peng (2016), who said transformational leaders encourage employees to go above and beyond the expected, while seeking shifts in their employees' values, attitudes, behaviors, morals, and needs. All participants indicated the importance of employee and leadership relationships for addressing the organization's goals, as keeping employees engaged results in increased profits.

\section{Discussion, Evaluation of Findings, and Conclusions}

Leaders that are authentic influence the engagement of employees (Nicholas \& Erakovich, 2013). To make or maintain their companies' profitability, business leaders must work hard to engage employees (Kortmann et al., 2014). Improved employee engagement is a byproduct of leaders who have a direct relationship with employees (Lowe, 2012). The findings of this research indicated that the bond between leaders and employees is an essential element for engaging employees, which in turn increased organizational profitability. Sadeghi and Pihie (2012) suggested organizations should look for leaders that can both communicate the organization's vision and secure employees' support in achieving organizational goals.

Engaged employees deliver improved organizational and individual performance. Tonkham (2013) suggested that leaders become more creative and apply creativity within the workplace. Communication business leaders must understand the need for autonomy, intrinsic rewards, and influence to achieve employee engagement (Bolman \& Deal, 2014). Based on the findings from this 
research, organizations attract employees who are willing to be engaged, which leads to an increase in employee engagement that results in high profitability. Therefore, the organization is less effective when employees are not motivated to do their jobs, as this directly affects job performance. Leaders who implement employee engagement strategies noted (a) higher levels of employee engagement (Blattner \& Walter, 2015); (b) improved customer satisfaction, productivity, and profit (Bowen, 2016); and, (c) lower levels of employee accidents and turnovers (Barrick et al., 2014). The study findings indicated leaders who monitor the recurrent reasons employees become disengaged, can provide valuable feedback to improve employee engagement.

Three themes emerged from the research: (a) rewards and recognition, (b) empowering employees, and (c) building a bond between leaders and employees. If business leaders incorporate these three themes into their leadership practice, they could create growth potential for the organization. The findings indicated that implementing successful employee engagement strategies is critical to organizational success and leaders who embark on an employee engagement strategy must develop good listening techniques, be fair, have and demonstrate respect, build trust, and understand the employees' concerns. Employee engagement has emerged as one of the greatest challenges in today's workplace. With the complexities and stringent regulations in many organizations today, employee engagement will continue to challenge organizations in the future (Mishra et al., 2014). Employee engagement is a critical element in maintaining the organization's vitality, survivability, and profitability (Albercht et al., 2015; Breevaart et al., 2013; Farndale \& Murrer, 2015).

The primary determinants of organizational effectiveness are job involvement and trust (Nasomboon, 2014). Setting expectations helps to create employee motivation (Swarnalatha \& Prasanna, 2013). Mentoring is the process of developing a mutually beneficial relationship involving two or more people with the same goal of achieving excellent professional outcomes (McCuiston \& DeLucenay, 2010). A leader's capability to successfully leverage employee engagement strategies is essential to organizational achievement. By applying effective employee engagement strategies, business leaders could achieve improved employee performance and yield greater organizational profitability.

The study can provide a foundation for organizational leaders currently implementing some of the strategies identified but may lack strategies which can improve employee engagement. Improving employee engagement strategies is essential to an organization's profitability. Disengaged employees will result in reduced workplace productivity and decreased customer service skills.

Based on the results, four practical actions are recommended. The first recommendation is communication organizations would benefit from focusing more on (a) rewards and recognition, (b) empowering employees, and (c) building a bond between leaders and employees as strategic objectives. The rising level of disengaged employees can have a significant impact on an organization's profit, ability to retain skilled employees, and employee citizenship (Berens, 2013).

The second recommendation is utilizing management's capability to leverage employee engagement strategies in an organization. The application of effective employee engagement strategies may assist business leaders in successfully engaging employees and sustaining profitability. Improving employee engagement will positively affect an employee's job performance and organizational profitability (Mann \& Darby, 2014). All participants agreed the need for leadership focus and support to improve employee engagement is imperative.

The third recommendation is that communication business leaders could benefit from considering the study findings that contribute to improved business practices and positive social change. Supported by Cooper-Thomas et al. (2014), and as indicated in the findings, communication business leaders must understand the relationship between employee engagement and organizational profitability, and there should be an investment in improving employee engagement strategies. Well- 
developed employee engagement strategies could close the gap between employee motivation and optimal job performance by incorporating employee needs.

The fourth and last recommendation is organizational leaders could use the results to create leadership strategies that could raise employee engagement and job performance. Business leaders can conduct quarterly employee surveys with employees to develop a better understanding of the employees' expectation trends over time. Monitoring and tracking employee engagement strategies of an organization and its competitors can be useful when planning to implement effective employee engagement strategies. To reach maximum results for the organization, most business leaders plan to increase productivity. To increase overall profitability, improvements in employee engagement should be an organizational goal.

Given the selected method and design, this study had limitations that can be addressed by additional topical research. For example, the absence of other organizational members was a limitation of this study. The employee engagement strategies identified in this study merit investigation from the viewpoints of other organizational members. Further studies may be necessary to understand the correlations between other members and employee engagement in the communication industry. Further research is recommended on employee engagement strategies used by business leaders in other geographical locations and industries, as this study focused on communication business in Jackson. Future research should determine how these findings could be transferable to other organizations and locations.

\section{References}

Ahmetoglu, G., Harding, X., Akhtar, R., \& Chamorro-Premuzic, T. (2015). Predictors of creative achievement: Assessing the impact of entrepreneurial potential, perfectionism, and employee engagement. Creativity Research Journal, 27, 198-205. doi:10.1080/10400419.2015.1030293

Albercht, S. L., Bakker, A. B., Gruman, J. A., Macey, W. H., \& Saks, A. M. (2015). Employee engagement, human resource management practices and competitive advantage: An integrated approach. Journal of Organizational Effectiveness: People and Performance, 2, 7 35. doi:10.1108/joepp-08-2014-0042

Anderson, C. A., Leahy, M. J., DelValle, R., Sherman, S., \& Tansey, T. N. (2014). Methodological application of multiple case study design using modified consensual qualitative research $(\mathrm{CQR})$ analysis to identify best practices and organizational factors in the public rehabilitation program. Journal of Vocational Rehabilitation, 41, 87-98. doi:10.3233/JVR140709

Andrew, O. C., \& Sofian, S. (2012). Individual factors and work outcomes of employee engagement. Procedia: Social and Behavioral Sciences, 40, 498-508. doi:10.1016/j.sbspro.2012.03.222

Anitha, J. (2014). Determinants of employee engagement and their impact on employee performance. International Journal of Productivity and Performance Management, 63, 308-323. doi:10.1108/ijppm-01-2013-0008

Avey, J. B., Wernsing, T. S., \& Palanski, M. E. (2012). Exploring the process of ethical leadership: The mediating role of employee voice and psychological ownership. Journal of Business Ethics, 107, 21-34. doi:10.1007/s10551-012-1298-2

Barrick, M. R., Thurgood, G. R., Smith, T. A., \& Courtright, S. H. (2014). Collective organizational engagement: Linking motivational antecedents, strategic implementation, and firm performance. Academy of Management Journal, 58, 111-135. doi:10.5465/amj.2013.0227

Basurto, X., \& Speer, J. (2012). Structuring the calibration of qualitative data as sets for qualitative comparative analysis. Field Methods, 24, 155-174. doi:10.1177/1525822X11433998 
Beck, R., \& Harter, J. (2015, April 21). Managers account for 70\% of variance in employee engagement. Gallup Business Journal. Retrieved from http://www.gallup.com/businessjournal/182792/managers-account-variance-employeeengagement.aspx

Belle, S. M., Burley, D. L., \& Long, S. D. (2014). Where do I belong? High-intensity teleworkers' experience of organizational belonging. Human Resource Development International, 18, 7696. doi:10.1080/13678868.2014.979006

Berens, R. (2013). The roots of employee engagement: A strategic approach. Employment Relations Today, 40, 43-49. doi:10.1002/ert.21420

Bersin, J. (2014, March 15). Why companies fail to engage today's workforce: The overwhelmed employee. Forbes. Retrieved from https://www.forbes.com/sites/joshbersin/2014/03/15/whycompanies-fail-to-engage-todays-workforce-the-overwhelmed-employee/\#34880e894726

Bezrukova, K., Thatcher, S. M. B., Jehn, K. A., \& Spell, C. S. (2012). The effects of alignment: Examining group faultlines, organizational cultures, and performances. Journal of Applied Psychology, 97, 77-92. doi:10.1037/a0023684

Blattner, J., \& Walter, T. J. (2015). Creating and sustaining a highly engaged company culture in a multigenerational workplace. Strategic HR Review, 14, 124-130. doi:10.1108/shr-06-20150043

Bolman, L. G., \& Deal, T. E. (2014). How great leaders think: The art of reframing. San Francisco, CA: Jossey-Bass.

Bowen, D. E. (2016). The changing role of employees in service theory and practice: An interdisciplinary view. Human Resource Management Review, 26, 4-13. doi:10.1016/j.hrmr.2015.09.002

Breevaart, K., Bakker, A., Hetland, J., Demerouti, E., Olsen, O. K., \& Espevik, R. (2013). Daily transactional and transformational leadership and daily employee engagement. Journal of Occupational and Organizational Psychology, 87, 138-157. doi:10.1111/joop.12041

Brick, W. P. (2012, December 14). Employee recognition programs critical to workplace culture. The Public Manager. Retrieved from https://www.td.org/Publications/Magazines/The-PublicManager/Archives/2012/Winter/Employee-Recognition-Programs

Bruin, M., McCambridge, J., \& Prins, J. M. (2014). Reducing the risk of bias health behaviour change trials: Improving trial design, reporting or bias assessment criteria? A review and case study. Psychology and Health, 30, 8-34. doi:10.1080/08870446.2014.953531

Butler, S. S., Brennan-Ing, M., Wardamasky, S., \& Ashley, A. (2014). Determinants of longer job tenure among home care aides: What makes some stay on the job while others leave? Journal of Applied Gerontology, 33, 164-188. doi:10.1177/0733464813495958

Buttner, E. E., Lowe, K., \& Billings-Harris, L. (2012). An empirical test of diversity climate dimensionality and relative effects on employee of color outcomes. Journal of Business Ethics, 110, 247-258. doi:10.1007/s10551-011-1179-0

Cairney, P., \& St. Denny, E. (2014). What is qualitative research (Bloomsbury). International Journal of Social Research Methodology, 18, 117-125. doi:10.1080/13645579.2014.957434

Carter, B. (2015, September 29). 4 dramatic shifts in the workplace that will positively affect employee engagement [Blog post]. Retrieved from http://blog.accessdevelopment.com/4dramatic-shifts-in-the-workplace-that-will-positively-affect-employee-engagement 
Choudhary, A. I., Akhtar, S. A., \& Zaheer, A. (2012). Impact of transformational and servant leadership on organizational performance: A comparative analysis. Journal of Business Ethics, 116, 433-440. doi:10.1007/s10551-012-1470-8

Cooper-Thomas, H. D., Paterson, N. L., Stadler, M. J., \& Saks, A. M. (2014). The relative importance of proactive behaviors and outcomes for predicting newcomer learning, well-being, and work engagement. Journal of Vocational Behavior, 84, 318-331. doi:10.1016/j.jvb.2014.02.007

Crossman, B., \& Crossman, J. (2011). Conceptualising followership: A review of the literature. Leadership, 7, 481-497. doi:10.1177/1742715011416891

Deci, E. L., \& Ryan, R. M. (1985). Intrinsic motivation and self-determination in human behavior. New York, NY: Plenum.

Dollard, M. F., \& Bakker, A. B. (2010). Psychological safety climate as a precursor to conductive work environments, psychological health problems, and employee engagement. Journal of Occupational and Organizational Psychology, 83, 579-599. doi:10.1348/096317909x470690

Eldor, L., \& Harpaz, I. (2015). A process model of employee engagement: The learning climate and its relationship with extra-role performance behaviors. Journal of Organizational Behavior, 37, 213-235. doi:10.1002/job.2037

Emrouznejad, A., Anouze, A. L., \& Thanassoulis, E. (2010). A semi-oriented radial measure for measuring the efficiency of decision making units with negative data, using DEA. European Journal of Operational Research, 200, 297-304. doi:10.1016/j.ejor.2009.01.001

Farndale, E., \& Murrer, I. (2015). Job resources and employee engagement: A cross-national study. Journal of Managerial Psychology, 30, 610-626. doi:10.1108/jmp-09-2013-0318

Fehr, R., \& Gelfand, M. J. (2012). The forgiving organization: A multilevel model of forgiveness at work. Academy of Management Review, 37, 664-688. doi:10.5465/amr.2010.0497

Festing, M., \& Schafer, L. (2014). Generational challenges to talent management: A framework for talent retention based on the psychological-contract perspective. Journal of World Business, 49, 262-271. doi:10.1016/j.jwb.2013.11.010

Fullagar, C. J., \& Mills, M. J. (2008). Motivation and flow: Towards an understanding of the dynamics of the relation in architecture students. The Journal of Psychology, 142, 533-556. doi:10.3200/jrlp.142.5.533-556

Gilbert, L. S., Jackson, K., \& DiGregorio, S. (2013). Tools for analyzing qualitative data: The history and relevance of qualitative data analysis software. In J. M. Spector, M. D. Merrill, J. Elen, \& M. J. Bishop (Eds.), Handbook of research on educational communications and technology (pp. 221-236). New York, NY: Springer. doi:10.1007/978-1-4614-3185-5_18

Granatino, R., Verkamp, J., \& Parker, R. S. (2013). The use of secret shopping as a method of increasing engagement in the healthcare industry: A case study. International Journal of Healthcare Management, 6, 114-121. doi:10.1179/2047971913y.0000000039

Haines, V. Y., \& St-Onge, S. (2012). Performance management effectiveness: Practices or context? The International Journal of Human Resource Management, 23, 1158-1175. doi:10.1080/09585192.2011.561230

Hausknecht, J. P., \& Holwerda, J. A. (2013). When does employee turnover matter? Dynamic member configurations, productive capacity, and collective performance. Organization Science, 24, 210-225. doi:10.1287/orsc.1110.0720

Hayes, T. M. (2015). Demographic characteristics predicting employee turnover intentions (Doctoral dissertation). Available from ProQuest Dissertation and Theses database. (UMI No. 3728489) 
Hill, S. A., \& Birkinshaw, J. (2012). Ambidexterity and survival in corporate venture units. Journal of Management, 40, 1899-1931. doi:10.1177/0149206312445925

Hynes, G. E. (2012). Improving employees' interpersonal communication competencies: A qualitative study. Business Communication Quarterly, 75, 466-475. doi:10.1177/1080569912458965

Johnson, P. (2015). Evaluating qualitative research: Past, present and future. Qualitative Research in Organizations and Management: An International Journal, 10, 320-324. doi:10.1108/QROM-07-2015-1303

Karanges, E., Johnston, K., Beatson, A., \& Lings, I. (2015). The influence of internal communication on employee engagement: A pilot study. Public Relations Review, 41, 129-131. doi:10.1016/j.pubrev.2014.12.003

Kompaso, S. M., \& Sridevi, M. S. (2010). Employee engagement: The key to improving performance. International Journal of Business and Management, 5, 89-98. doi:10.5539/ijbm.v5n12p89

Kortmann, S., Gelhard, C., Zimmermann, C., \& Piller, F. (2014). Linking strategic flexibility and operational efficiency: The mediating role of ambidextrous operational capabilities. Journal of Operations Management, 32, 475-490. doi:10.1016/j.jom.201.09.007

Korzynski, P. (2013). Employee motivation in new working environment. International Journal of Academic Research, 5, 184-188. doi:10.7813/2075-4124.2013/5-5/b.28

Kouzes, J. M., \& Posner, B. Z. (2012). The leadership challenge: How to make extraordinary things happen in organizations (5th ed.). San Francisco, CA: Jossey-Bass.

La Guardia, J. G. (2009). Developing who I am: A self-determination theory approach to the establishment of healthy identities. Educational Psychologist, 44, 90-104. doi:10.1080/00461520902832350

Lalor, J. G., Casey, D., Elliott, N., Coyne, I., Comiskey, C., Higgins, A., ... Begley, C. (2013). Using case study within a sequential explanatory design to evaluate the impact of specialist and advanced practice roles on clinical outcomes: The SCAPE study. BMC Medical Research Methodology, 13, 55. doi:10.1186/1471-2288-13-55

Latif, K. F. (2012). An integrated model of training effectiveness and satisfaction with employee development interventions. Industrial and Commercial Training, 44, 211-222. doi:10.1108/0019785121123147

Ledlow, G. J. R., \& Coppola, M. N. (2013). Leadership for health professionals (2nd ed.). Burlington, MA: Jones \& Barlett Learning.

Li, L., \& Titsworth, S. (2015). Student misbehaviors in online classrooms: Scale development and validation. American Journal of Distance Education, 29, 41-55. doi:10.1080/08923647.2015.994360

Li, Z., Gupta, B., Loon, M., \& Casimir, G. (2016). Combinative aspects of leadership style and emotional intelligence. Leadership \& Organization Development Journal, 37, 107-125. doi:10.1108/lodj-04-2014-0082

Lowe, G. (2012). How employee engagement matters for hospital performance. Healthcare Quarterly, 15, 29-39. doi:10.12927/hcq.2012.22915

Mann, A., \& Darby, R. (2014, August 5). Should managers focus on performance or engagement? Gallup Business Journal. Retrieved from http://www.gallup.com/businessjournal/174197/managers-focus-performanceengagement.aspx

Marshall, C., \& Rossman, G. B. (2014). Designing qualitative research (6th ed.). Thousand Oaks, CA: Sage. 
McCuiston, V. E., \& DeLucenay, A. (2010). Organization development quality improvement process: Progress energy's continuous business excellence initiative. Journal of Business Case Studies, 6, 7-18. doi:10.19030/jbcs.v6i6.255

McDaniel, K. R., Ngaia, F., \& Leonard, K. M. (2015). Does competency matter? Competency as a factor in workplace bullying. Journal of Managerial Psychology, 30, 597-609. doi:10.1108/jmp-02-2013-0046

Men, L. R., \& Stacks, D. W. (2013). The impact of leadership style and employee empowerment on perceived organizational reputation. Journal of Communication Management, 17, 171-192. doi:10.1108/13632541311318765

Menguc, B., Auh, S., Fisher, M., \& Haddad, A. (2013). To be engaged or not to be engaged: The antecedents and consequences of service employee engagement. Journal of Business Research, 66, 2163-2710. doi:10.1016/j.jbusres.2012.01.007

Meyer, J. P., Stanley, L. J., \& Parfyonova, N. M. (2012). Employee commitment in context: The nature and implication of commitment profiles. Journal of Vocational Behavior, 80, 1-16. doi:10.1016/j.jvb.2011.07.002

Mishra, K., Boynton, L., \& Mishra, A. (2014). Driving employee engagement: The expanded role of internal communications. International Journal of Business Communications, 51, 183-202. doi:10.1177/2329488414525399

Morgeson, F. P., Aquinis, H., Waldman, D. A., \& Siegel, D. S. (2013). Extending corporate social responsibility research to the human resource management and organizational behavior domains: A look to the future. Personnel Psychology, 66, 805-824. doi:10.1111/peps.12055

Mowbray, P. K., Wilkinson, A., \& Tse, H. H. M. (2014). An integrative review of employee voice: Identifying a common conceptualization and research agenda. International Journal of Management Reviews, 17, 382-400. doi:10.1111/ijmr.12045

Mullen, C. A., Fish, V. L., \& Hutinger, J. L. (2010). Mentoring doctoral students through scholastic engagement: Adult learning principles in action. Journal of Further and Higher Education, 34, 179-197. doi:10.1080/03098771003695452

Musgrove, C., Ellinger, A. E., \& Ellinger, A. D. (2014). Examining the influence of strategic profit emphases on employee engagement and service climate. Journal of Workplace Learning, 26, 152-171. doi:10.1108/JWL-08-2013-0057

Nasomboon, B. (2014). The relationship among leadership commitment organizational performance and employee engagement. International Business Research, 7, 77-90. doi:10.5539/ibr.v7n9p77

Nicholas, T. W., \& Erakovic, R. (2013). Authentic leadership and implicit theory: A normative form of leadership. Leadership \& Organization Development Journal, 34, 182-195. doi:10.1108/01437731311321931

Purcell, J. (2014). Disengaging from engagement. Human Resource Management Journal, 24, 241254. doi:10.1111/1748-8583.12046

Saber, D. A. (2013). Generational differences of the frontline nursing workforce in relation to job satisfaction: What does the literature reveal? The Health Care Manager, 32, 329-335. doi:10.1097/HCM.0b013e3182a9d7ad

Sadeghi, A., \& Pihie, Z. A. L. (2012). Transformational leadership and its predictive effects on leadership effectiveness. International Journal of Business \& Social Science, 3, 186-197. 
Saks, A., \& Gruman, J. A. (2014). Making organizations more effective through organizational socialization. Journal of Organizational Effectiveness: People and Performance, 1, 261-280. doi:10.1108/joepp-07-2014-0036

Schaubroeck, J. M., Lam, S. S. K., \& Peng, A. C. (2016). Can peers' ethical and transformational leadership improve coworkers' service quality? A latent growth analysis. Organizational Behavior and Human Decision Processes, 133, 45-58. doi:10.1016/j.obhdp.2016.02.002

Schramm, J., Coombs, J., \& Boyd, R. (2013). SHRM workplace forecast: The top workplace trends according to the HR professionals. Retrieved from https://www.shrm.org/Research/FutureWorkplaceTrends/Documents/130146\%20Workplace_Forecast_FULL_FNL.pdf

Shahid, A., \& Azhar, S. M. (2013). Gaining employee commitment: Linking to organizational effectiveness. Journal of Management Research, 5, 250-268. doi:10.5296/jmr.v5i1.2319

Silverman, D. (2015). Interpreting qualitative data (5th ed.). Thousand Oaks, CA: Sage.

Slack, F. J., Orife, J. N., \& Anderson, F. P. (2010). Effects of commitment to corporate vision on employee satisfaction with their organization: An empirical study in the United States. International Journal of Management, 27, 421-436.

Society for Human Resource Management (SHRM). (2014). Employee job satisfaction and engagement: The road to economic recovery. Retrieved from https://www.shrm.org/hrtoday/trends-and-forecasting/research-and-surveys/Documents/140028\%20JobSatEngage_Report_FULL_FNL.pdf

Song, J. H., Kolb, J. A., Lee, U. H., \& Kim, H. K. (2012). Role of transformational leadership in effective organizational knowledge creation practices: Mediating effects of employees' work engagement. Human Resource Development Quarterly, 23, 65-101. doi:10.1002/hrdq.21120

Souba, W. W. (2011). The being of leadership. Philosophy, Ethics, and Humanities in Medicine, 6, 111. doi:10.1186/1747-5341-6-5

Swarnalatha, C., \& Prasanna, T. S. (2013). Employee engagement and line of sight. International Journal of Research in Business Management, 1, 1-8.

Talib. F. (2013). An overview of total quality management: Understanding the fundamentals in service organization. International Journal of Advanced Quality Management, 1, 1-20.

Tonkham, M. R. (2013). The road to magnet: Encouraging transformational leadership. AORN Journal, 98, 186-188. doi:10.1016/j.aorn.2013.05.007

Ugwu, F. O., Onyishi, I. E., \& Rodriguez-Sanchez, A. M. (2014). Linking organizational trust with employee engagement: The role of psychological empowerment. Personnel Review, 43, 377400. doi:10.1108/pr-11-2012-0198

U.S. Department of Labor. (2015). Employee engagement strategy final report. Retrieved from http://www.dol.gov/odep/pdf/20150201EESFinalReport.pdf

Vallerand, R. J. (2012). From motivation to passion: In search of the motivational processes involved in a meaningful life. Canadian Psychology, 53, 42-52. doi:10.1037/a0026377

Vandenabeele, W. (2014). Explaining public service motivation: The role of leadership and basic needs satisfaction. Review of Public Personnel Administration, 34, 153-173. doi:10.1177/0734371x14521458

Wang, D., \& Chia-Chun, H. (2013). The effect of authentic leadership on employee trust and employee engagement. Social Behavior and Personality: An International Journal, 41, 613324. doi:10.2224/sbp.2013.41.4.613 
Welch, M. (2012). Appropriateness and acceptability: Employee perspectives of internal communication. Public Relations Review, 38, 246-254.

Yin, R. K. (2013). Case study research: Design and methods (5th ed.). Thousand Oaks, CA: Sage.

Yuan, B. J., \& Lin, M. B., Shieh, J. H., \& Li, K. P. (2012). Transforming employee engagement into long-term customer relationships: Evidence from information technology salespeople in Taiwan. Social Behavior and Personality: An International Journal, 40, 1549-1554. doi:10.2224/sbp.2012.40.9.1549

Yukl, G. A. (2012). Leadership in organizations (8th ed.). Salem, OR: Prentice Hall.

The International Journal of Applied Management and Technology (IJAMT), sponsored by Walden University's School of Management, is a peer-reviewed, online journal that addresses contemporary national and international issues related to management and technology. The objectives of the IJAMT are to: (a) encourage collaborative and multi-disciplinary examinations of important issues in business and technology management, and (B) engage scholars and scholar-practitioners in a dynamic and important dialogue.

Walden University Publishing: http://www.publishing.waldenu.edu 